MACROECONOMIA E CONJUNTURA

\title{
Câmbio real e crescimento econômico ${ }^{\dagger}$
}

Affonso Celso Pastore*

RESUMO - Os críticos do atual regime cambial brasileiro propõem que o governo exerça maior grau de arbítrio, sustentando a taxa cambial em um nível permanentemente mais depreciado. Com isso, segundo eles, o Brasil geraria um aumento das exportações líquidas, provocando superávits nas contas correntes e transformando-se em um exportador de capitais, mas colhendo, em contrapartida, a aceleração do crescimento econômico. Mas será que a pura e simples manutenção do câmbio mais depreciado nos levaria de fato ao crescimento acelerado e a superávits nas contas correntes?

Para responder a essa indagação, temos de ir além da definição contábil de que os superávits nas contas correntes são o excesso de exportações sobre as importações de bens e serviços. Do ponto de vista econômico, o país gera superávits quando e somente quando poupa domesticamente mais do que investe, o que significa que gera um produto maior do que a demanda total doméstica.

A China tem uma taxa de investimentos perto de $45 \%$ do PIB, que é o triplo da média brasileira dos últimos anos, mas tem taxas de poupança ainda maiores. A demanda doméstica menor do que a produção é consequência do fato de sua poupança ser maior que os investimentos, explicando a geração dos superávits nas contas correntes. É a enorme taxa de investimentos, de 45\% do PIB, que explica o seu sucesso em manter taxas de crescimento tão elevadas, e é o excesso das poupanças domésticas sobre os investimentos que explica os superávits nas contas correntes.

O Brasil, ao contrário, tem poupanças domésticas baixas, e sempre que a taxa de investimentos aumenta, acelerando o crescimento do PIB, surgem déficits nas contas correntes. O Brasil não é um exportador de capitais, e os investimentos exigem a complementação das poupanças externas, que são importadas através dos déficits nas contas correntes.

Os dados das contas nacionais mostram que, quando os déficits nas contas correntes se elevam, há também alguma elevação do consumo, o que indica que existe alguma substituição de poupanças domésticas por poupanças externas. Mas essa substituição é apenas

† Artigo publicado originalmente no jornal O Estado de S. Paulo, 28 de Fevereiro de 2010.

* Doutor em Economia, professor de economia da FGV-RJ e ex-Presidente do Banco Central. 
parcial, porque a maior parte dos déficits se destina a financiar o aumento dos investimentos, e não do consumo.

Quem duvidar dessa proposição é convidado a procurar os dados das contas nacionais, e dividir tanto a formação bruta de capital fixo (os investimentos) quanto as importações líquidas (o déficit nas contas correntes) pelo PIB, superpondo as duas séries. Quem fizer isso vai assustar-se com a forte correlação entre as duas séries, mostrando que sempre que os déficits em contas correntes se elevam crescem, também, as taxas de investimento. Conclui-se que as poupanças externas são predominantemente usadas para elevar a capacidade produtiva, contribuindo para o crescimento econômico.

Diante dessa evidência, o Brasil tem pela frente dois caminhos para manter taxas elevadas de crescimento. O primeiro é alterar radicalmente suas políticas econômicas, visando a elevar as poupanças totais domésticas, livrando-se da dependência das poupanças externas. Para tanto, teria de começar elevando a poupança do governo, reduzindo os gastos públicos correntes e as transferências de renda que estimulam o consumo privado.

Mas, na ausência de uma inflação inesperada, que corte gastos públicos em termos reais, sua redução seria extremamente lenta e exigiria um esforço enorme. Não nos parece que esse objetivo esteja na agenda de qualquer candidato a presidente da República. Por isso, não tenho esperanças de trilharmos o caminho chinês.

O segundo caminho é aceitar que as poupanças domésticas são baixas e, para acelerar o crescimento econômico, teremos de conviver com os déficits mais elevados nas contas correntes. Como essa parece ser a escolha mais provável, cabe discutir os limites, as consequências e os riscos dessa opção.

Uma consequência está associada à valorização cambial. Um aumento das importações líquidas de bens e serviços somente se dá com o câmbio real valorizado, o que pode ocorrer ou através de ingressos de capitais que valorizem o câmbio nominal ou através de maior inflação. Se fosse possível impedir, ainda que parcialmente, os ingressos de capitais, o País não teria como financiar a totalidade dos déficits nas contas correntes necessários para elevar as poupanças que faltam para financiar os investimentos maiores. $\mathrm{O}$ câmbio real seria mais depreciado, mas as taxas de crescimento econômico seriam menores.

Qual é o limite para esses déficits nas contas correntes? Da mesma forma como qualquer governo colhe o aumento da dívida pública ao gerar déficits públicos, o País vê seu passivo externo líquido crescer quando acumula déficits persistentes nas contas correntes, 
quer esse passivo ocorra na forma de dívida externa (pública e privada), quer ocorra na forma de investimentos (diretos ou em ações).

Embora seja preferível um passivo maior na forma de investimentos do que na forma de dívida (os investimentos trazem mais tecnologia, aumentando a produtividade), em ambos os casos são gerados encargos. Em economia "não há almoço gratuito". Um passivo acumulado na forma de dívida externa (pública ou privada) gera o encargo dos juros e, se for acumulado na forma de investimentos diretos (ou de ações), gera o encargo dos lucros e dividendos.

Por isso, países com um passivo maior têm um câmbio real de equilíbrio mais depreciado. Em 2002, o passivo externo líquido brasileiro caminhava em torno de $50 \%$ do $\mathrm{PIB}$, por isso o câmbio real de equilíbrio teria de ser, como era, mais depreciado do que em 2008, quando o passivo externo brasileiro era bem menor, em torno de $20 \%$ do PIB.

Se estivermos diante de uma sequência de anos de taxas mais elevadas de investimento, temos de estar preparados para uma sequência de anos de déficits mais elevados nas contas correntes, o que significa uma elevação contínua do nosso passivo externo líquido.

Os déficits nas contas correntes muito elevados contêm a semente de sua própria destruição ao exigirem, depois de algum tempo, a depreciação do câmbio real de equilíbrio para financiar os encargos de um passivo externo líquido mais elevado. Poderemos crescer temporariamente mais apenas enquanto a restrição imposta por um passivo externo mais elevado não nos tolher.

Ao consumir mais no presente, poupando menos, somos empurrados para a necessidade de absorver poupanças externas, que, por algum tempo, podem financiar taxas mais elevadas de investimento. Mas a absorção das poupanças externas tem limites, o que, por sua vez, coloca um limite às taxas de investimento. O ideal seria elevar as poupanças domésticas, reduzindo aquela limitação. Nada substitui a necessidade de enfrentar as reformas, no campo fiscal, que elevem as poupanças domésticas e preparem o País para um crescimento mais acelerado.

Neste ponto cabe uma advertência: aceitar um câmbio mais apreciado não significa aceitar um câmbio sobrevalorizado. Ondas de ingressos de capitais produzem ciclos de valorização do câmbio nominal, o que, diante do grau de inércia que existe nos preços nominais, pode levar o câmbio real atual abaixo do câmbio real de equilíbrio, provocando a sobrevalorização cambial. 
Os países emergentes são por vezes agredidos por ondas enormes de ingressos de capitais. Um tsunami como esse ocorreu nos anos 1990, logo após a fase mais aguda da crise da dívida dos anos 1980, e é essa a história de muitos países que cresceram acima de seus próprios meios no período anterior ao início da atual crise mundial, beneficiando-se dos ingressos de capitais gerados pela liquidez internacional excessiva.

O Brasil é, frequentemente, vítima dessas ondas de ingressos de capitais, e isso justifica que o Banco Central intervenha no mercado de câmbio para evitar uma valorização excessiva do real. Essas intervenções são legítimas e bem-vindas porque nos preparam para absorver choques externos, como ficou provado na atual crise mundial, e evitam que tenhamos a ilusão de um crescimento sustentável maior, quando estaríamos apenas criando uma crise futura.

Mas as intervenções para acumular reservas diferem de ações mais profundas, tentando controlar o próprio câmbio real, como querem os que buscam enquadrar o Brasil à força no modelo chinês de crescimento econômico. Entre outras coisas, as intervenções no mercado de câmbio devem permanecer exclusivamente nas mãos do Banco Central, não havendo nenhum sentido econômico para a criação de um fundo soberano de riqueza. Afinal, o Brasil não tem excesso de poupanças sobre os investimentos, o que, naturalmente, permitiria que investisse esse excesso em ativos no exterior.

$\mathrm{Na}$ qualidade de importador de capitais, um fundo soberano de riqueza somente pode acumular ativos internacionais gerando dívida pública, o que é um absoluto contrassenso. 